This document was prepared in conjunction with work accomplished under Contract No. DE-AC09-96SR18500 with the U. S. Department of Energy.

\title{
DISCLAIMER
}

This report was prepared as an account of work sponsored by an agency of the United States Government. Neither the United States Government nor any agency thereof, nor any of their employees, nor any of their contractors, subcontractors or their employees, makes any warranty, express or implied, or assumes any legal liability or responsibility for the accuracy, completeness, or any third party's use or the results of such use of any information, apparatus, product, or process disclosed, or represents that its use would not infringe privately owned rights. Reference herein to any specific commercial product, process, or service by trade name, trademark, manufacturer, or otherwise, does not necessarily constitute or imply its endorsement, recommendation, or favoring by the United States Government or any agency thereof or its contractors or subcontractors. The views and opinions of authors expressed herein do not necessarily state or reflect those of the United States Government or any agency thereof. 
Key Words:

TPBAR

Tritium

ILV

Low-Level Waste Disposal

Retention: Permanent

\section{SPECIAL ANALYSIS: \\ PRODUCTION TPBAR WASTE CONTAINER DISPOSAL WITHIN THE INTERMEDIATE LEVEL VAULT}

Robert A. Hiergesell

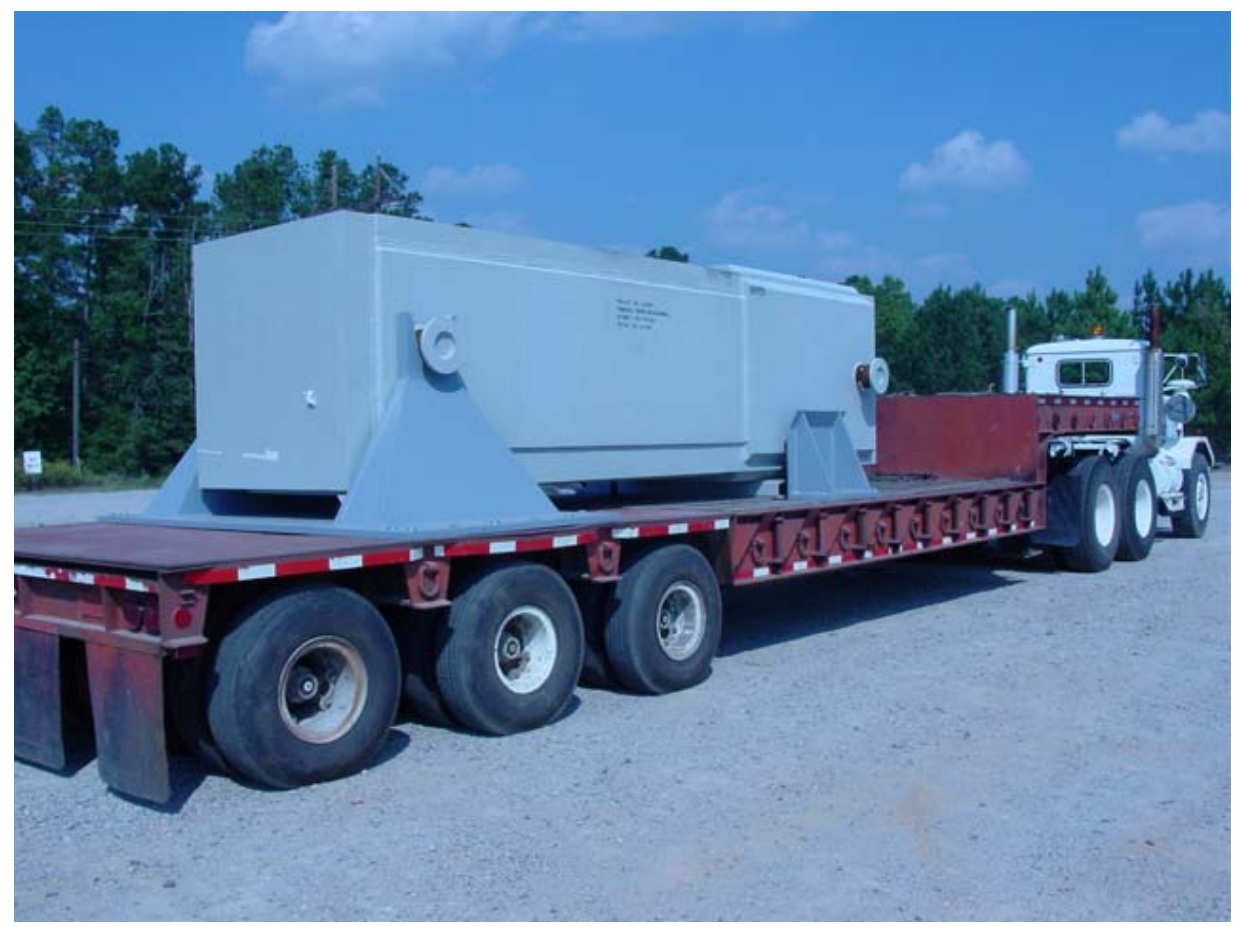

DECEMBER 2005

Westinghouse Savannah River Company

Savannah River Site

Aiken, SC 29808

Prepared for the U.S. Department of Energy Under

Contract Number DE-AC09-96SR18500

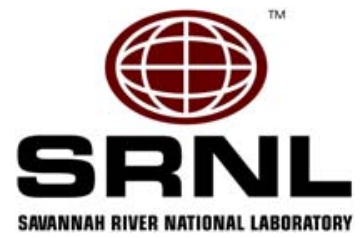




\section{DISCLAIMER}

This report was prepared for the United States Department of Energy under Contract No. DE-AC09-96SR18500 and is an account of work performed under that contract. Neither the United States Department of Energy, nor WSRC, nor any of their employees makes any warranty, expressed or implied, or assumes any legal liability or responsibility for accuracy, completeness, or usefulness, of any information, apparatus, or product or process disclosed herein or represents that its use will not infringe privately owned rights. Reference herein to any specific commercial product, process, or service by trade name, trademark, name, manufacturer or otherwise does not necessarily constitute or imply endorsement, recommendation, or favoring of same by Westinghouse Savannah River Company or by the United States Government or any agency thereof. The views and opinions of the authors expressed herein do not necessarily state or reflect those of the United States Government or any agency thereof.

Printed in the United States of America

Prepared For

U.S. Department of Energy 
Key Words:

TPBAR

Tritium

ILV

Low-Level Waste Disposal

Retention: Permanent

\section{SPECIAL ANALYSIS: \\ PRODUCTION TPBAR WASTE CONTAINER DISPOSAL WITHIN THE INTERMEDIATE LEVEL VAULT}

\section{Robert A. Hiergesell}

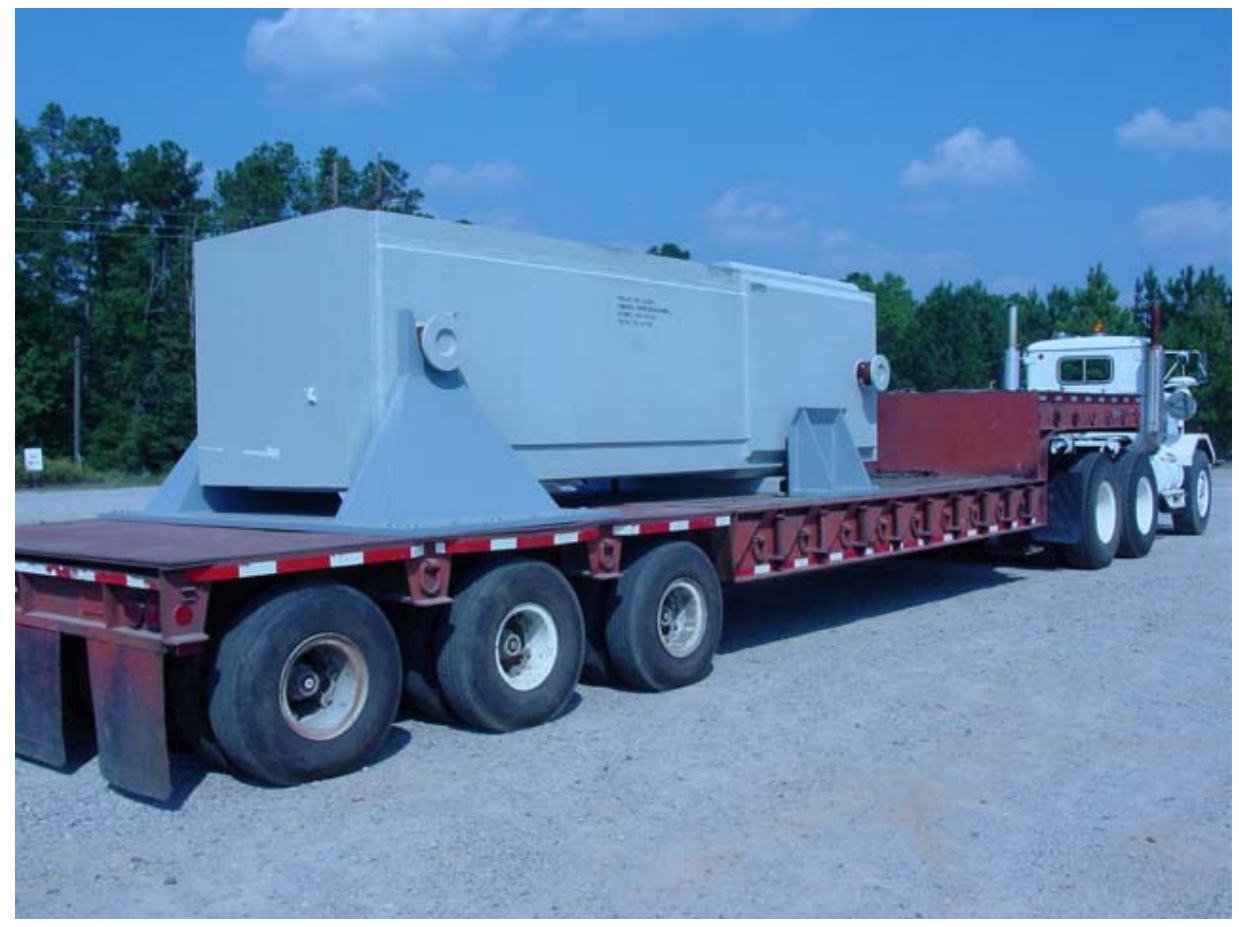

DECEMBER 2005

Westinghouse Savannah River Company

Savannah River Site

Aiken, SC 29808

Prepared for the U.S. Department of Energy Under

Contract Number DE-AC09-96SR18500

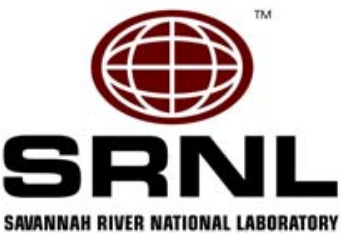




\section{REVIEWS AND APPROVALS}

Author

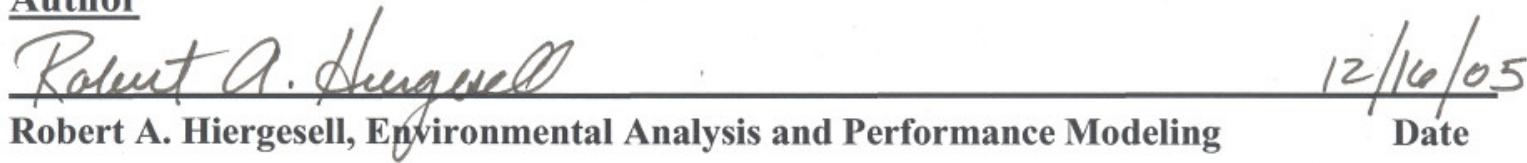

Design Check (per Manual E7, Procedure 2.60)

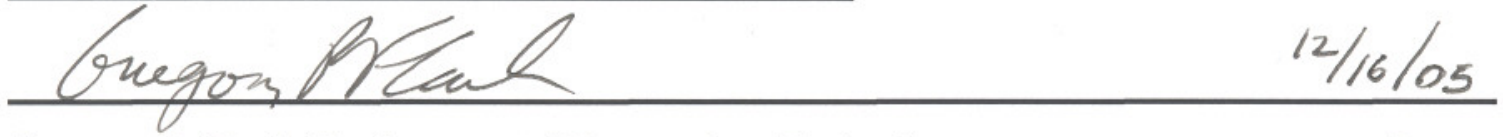

Gregory P. Flach, Environmental Restoration Technology

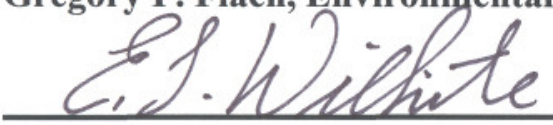

EImer L. Wilhite, Chemical Science and Technology

Date

\section{SRNL Approvals/Review}

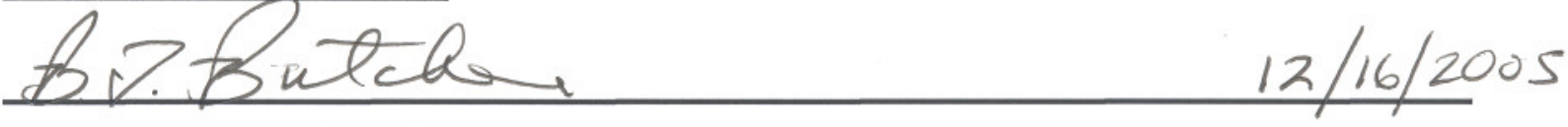

B.T. Butcher, L4 Manager, Environmental Analysis and Performance Modeling Date

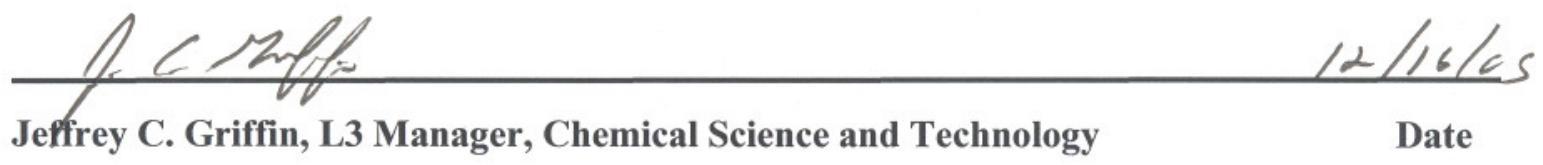

\section{Project Design and Construction Division Approvals}

Catherine A rlaisn 12/21/05

C.A. Flavin, Level 4 Manager, Defense Programs

Date

Solid Waste Division Approvals
(1) 3

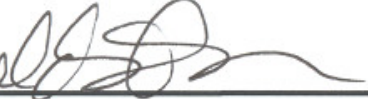
$12 / 21 / 05$

W.T. Goldston, Waste Management Area Project

Date

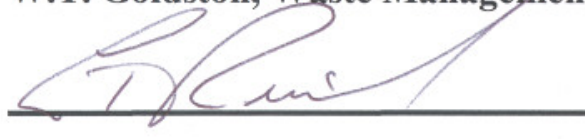

L.T. Reid, Waste Management Area Project, Engineering Manager

Date

hestone

Senvices

$12 / 21 / 05$

K.A. Stone, Waste Management Area Project,

Solid Waste Management Facility Manager

Date 


\section{TABLE OF CONTENTS}

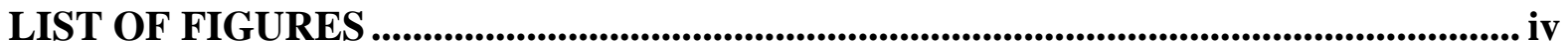

LIST OF TABLES ................................................................................................................ iv

LIST OF ACRONYMS ................................................................................................................ iv

EXECUTIVE SUMMARY .......................................................................................................... 1

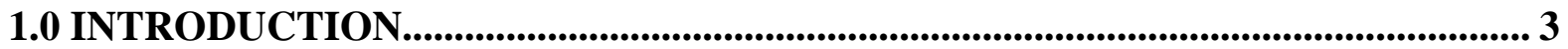

2.0 DISPOSAL CONTAINER CONCEPT.......................................................................... 4

3.0 TPBAR DISPOSAL CONTAINER RADIONUCLIDE INVENTORY ........................ 5

4.0 ILV DISPOSAL CONSIDERATIONS .......................................................................... 7

5.0 TRITIUM RELEASE FROM A PRODUCTION TPBAR CONTAINER ................. 14

6.0 ANALYSES ............................................................................................................................... 15

6.1 AIR AND RADON PATHWAY ANALYSES ............................................................. 15

6.1.1 SRS Boundary Analysis .................................................................................................... 15

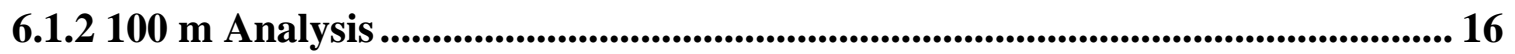

6.2 RESIDENT (INTRUDER) PATHWAY ANALYSIS.................................................... 16

6.3 GROUNDWATER PATHWAY ANALYSIS .............................................................. 17

7.0 RADIONUCLIDE DISPOSAL LIMITS ........................................................................... 22

8.0 CONCLUSIONS AND RECOMMENDATIONS......................................................... 23

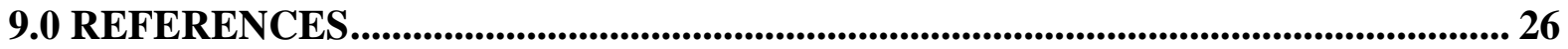

APPENDIX EMAIL TRANSMITTALS _............................................................................ 27 


\section{LIST OF FIGURES}

Figure 1. Sectional diagram of the TPBAR disposal container ................................................ 4

Figure 2. Heat field for TPBAR container fully encased in grout ........................................... 8

Figure 3. Waste container temperature profile and heat source term for 1200 TPBARs ..... 10

Figure 4. Tritium concentration in the vadose zone at 100 years ......................................... 18

Figure 5. Tritium flux at lower boundary of Vadose Zone model ....................................... 19

Figure 6. Tritium Concentration at the 100 meter compliance point .................................... 20

\section{LIST OF TABLES}

Table 1. Radionuclide Inventory for the Initial 17 TPBAR Disposal Containers .................... 6

Table 2. The Staggered Arrival Schedule of TPBAR Disposal Containers ........................... 12

Table 3. PNNL Unclassified Release Rate from a Fully Loaded TPBAR Container........... 14

Table 4. Radionuclide Limits for the Production TPBAR Disposal Containers ................... 22

Table 5. Summary of Inventory, Pathway Limits, and Fraction............................................ 22

\section{LIST OF ACRONYMS}

$\begin{array}{ll}\text { Btu } & \text { British thermal unit } \\ \text { Ci } & \text { curie } \\ \text { CLSM } & \text { consolidated low-strength material } \\ \text { DOE } & \text { U.S. Department of Energy } \\ \text { GW1 } & \text { Groundwater1 disposal limit (0-100 years) } \\ \text { GW2 } & \text { Groundwater2 disposal limit (100-1350 years) } \\ \text { ILV } & \text { Intermediate Level Vault } \\ \text { L } & \text { liters } \\ \text { m } & \text { meters } \\ \text { mrem } & \text { millirem } \\ \text { MCL } & \text { maximum contaminant level } \\ \text { NOAA } & \text { National Oceanic and Atmospheric Administration } \\ \text { PA } & \text { performance assessment } \\ \text { pCi } & \text { picocuries } \\ \text { PNNL } & \text { Pacific Northwest National Laboratory } \\ \text { SA } & \text { Special Analysis } \\ \text { SOF } & \text { sum-of-fractions } \\ \text { SRS } & \text { Savannah River Site } \\ \text { TEF } & \text { Tritium Extraction Facility } \\ \text { TVA } & \text { Tennessee Valley Authority } \\ \text { TPBAR } & \text { Tritium Producing Burnable Absorber Rod } \\ \text { WITS } & \text { Waste Information Tracking System }\end{array}$


WSRC-TR-2005-00531, Rev. 0

\section{EXECUTIVE SUMMARY}

The disposal of Tritium Producing Burnable Absorber Rods (TPBAR) waste containers produced as part of DOE's Tritium Readiness Program within the Intermediate Level Vault (ILV) was evaluated in this Special Analysis (SA). This program involves the irradiation of TPBARs in Tennessee Valley Authority (TVA) reactors prior to shipping them to SRS for tritium extraction at the Tritium Extraction Facility (TEF). The initial phase of this program will include TPBARs irradiated in Cycles 6-25 and will produce 17 waste containers for disposal in the ILV. Shipping of the initial production cycle TPBARs to SRS has already begun and will continue through 2022 according to a staggered schedule, as irradiation cycles are completed. Each waste container is expected to contain up to 1200 extracted TPBARs. This SA evaluates issues related to the loading of all 17 of the initial containers within the ILV, including heat load and general placement within the facility; and determination of which exposure pathways, if any, could result in human exposure and calculation of any relevant ILV disposal limits associated with the proposed action.

Because of the durability of the TPBAR containers within the disposal environment, non-tritium radionuclides will not be released until well beyond the 1000-year Performance Assessment (PA) time of compliance. Consequently, it was unnecessary to evaluate the air and groundwater pathways for non-tritium radionuclides; however an analysis was conducted for these radionuclides with respect to the inadvertent intruder pathway. Tritium, in the form of hydrogen, has the ability to permeate the exterior walls of the TPBAR containers and therefore evaluations were conducted to assess its potential to cause human exposure through the air, groundwater and resident (intruder) pathways. A detailed study of the groundwater pathway was conducted using the updated ILV vadose zone and groundwater models. The results of these analyses determined the tritium composite waste container Sum of Fractions (SOF) for the air, resident and groundwater (GW1 and GW2) pathways. These are 2.89E-05, 1.61E-03, 1.40E-03 and 1.39E-05, respectively. The limits for tritium calculated in this SA are unique to this waste package and will supersede the limits calculated for tritium in a previous SA that evaluated the initial TPBAR waste container (see Hiergesell and Wilhite, 2004).

The conclusion of this SA is that the initial 17 production TPBAR waste containers will not cause any exceedance of DOE Order 435.1 performance measures over the 1000-year PA compliance period and may be disposed of within the ILV. Furthermore, with the use of prudent management measures, the combined heat load contributed to the ILV by the 17 containers can be controlled such that no adverse impacts will be realized. 
WSRC-TR-2005-00531, Rev. 0

This page intentionally left blank. 
WSRC-TR-2005-00531, Rev. 0

\subsection{INTRODUCTION}

The Department of Energy's Tritium Readiness Program has identified a plan to provide an ongoing source of tritium. This program involves the irradiation of specially manufactured rods called Tritium Producing Burnable Absorber Rods (TPBARs) within two Tennessee Valley Authority (TVA) reactors. The irradiated rods would then be transported to the Savannah River Site (SRS) in NAC transportation casks that provide the necessary shielding, where they would be processed within the Tritium Extraction Facility (TEF) to remove the tritium. The plan then calls for four baskets of the extracted TPBARs to be loaded into the TEF shielded waste containers before they're welded shut. These waste containers will then be placed within a Low-Level Waste (LLW) disposal facility at the SRS. Irradiation of the TPBARs at the TVA reactors has already begun and is expected to continue through 2047. The first phase of TPBAR production is defined as those TPBARs produced in irradiation Cycles 6 through 25. The status of Cycles 6-25 were presented in a manager's briefing presented to NA-10 on September 27, 2005, in which the approximate irradiation schedule through 2022 was identified. This SA addresses only the proposed disposal of the anticipated 17 TEF waste containers that will contain TPBARs from Cycle 6-25 irradiation and further analysis will be required to identify a suitable disposal pathway for post-Cycle 25 TPBARs. Shipping of the first production cycle TPBARs to SRS has already begun and will continue through 2022 according to a staggered schedule as irradiation cycles are completed. The first of the 17 waste containers will house the Lead Test Assembly (LTA) in place of one of the four extraction baskets. The LTA is constructed of stainless steel and will contain 35 unextracted TPBARs from the Tritium Readiness Program's research efforts. The radionuclide inventory of the first TPBAR waste container, within which the LTA resides, is bounded by the radionuclide inventory of a typical production TPBAR waste container with four extraction baskets. The disposal of the first TPBAR waste container was evaluated in a previous SA (see Hiergesell and Wilhite, 2004) however, it is included in this SA as part of the 17 waste containers in this SA and therefore the limits calculated in this SA will supersede the limits calculated in the earlier SA.

The purpose of this SA is to evaluate the suitability of disposing the anticipated 17 initial-phase production TPBAR waste containers within the ILV. The scope of this SA included an evaluation of the following: determination of the radionuclide content of a single TPBAR waste container such that the total inventory for all 17 waste containers can be estimated; evaluation of issues related to the loading of all 17 waste containers within the ILV, including heat load and general placement within the facility; and determination of which exposure pathways, if any, could result in human exposure and calculation of any relevant ILV disposal limits associated with the proposed action. 


\subsection{WASTE CONTAINER CONCEPT}

TPBAR waste containers are rectangular carbon steel boxes with the approximate dimensions of 5feet (60-inches) by 5 -feet (60-inches) by $\sim 19$ feet (227-inches) long. The sides, top and bottom are all approximately 13 inches thick, as shown in Figure 1. The darkened area on the left-hand side of the drawing depicts the lid that is bolted on to provide shielding so that the 1-inch-thick outer closure can be welded on with a full-penetration weld.

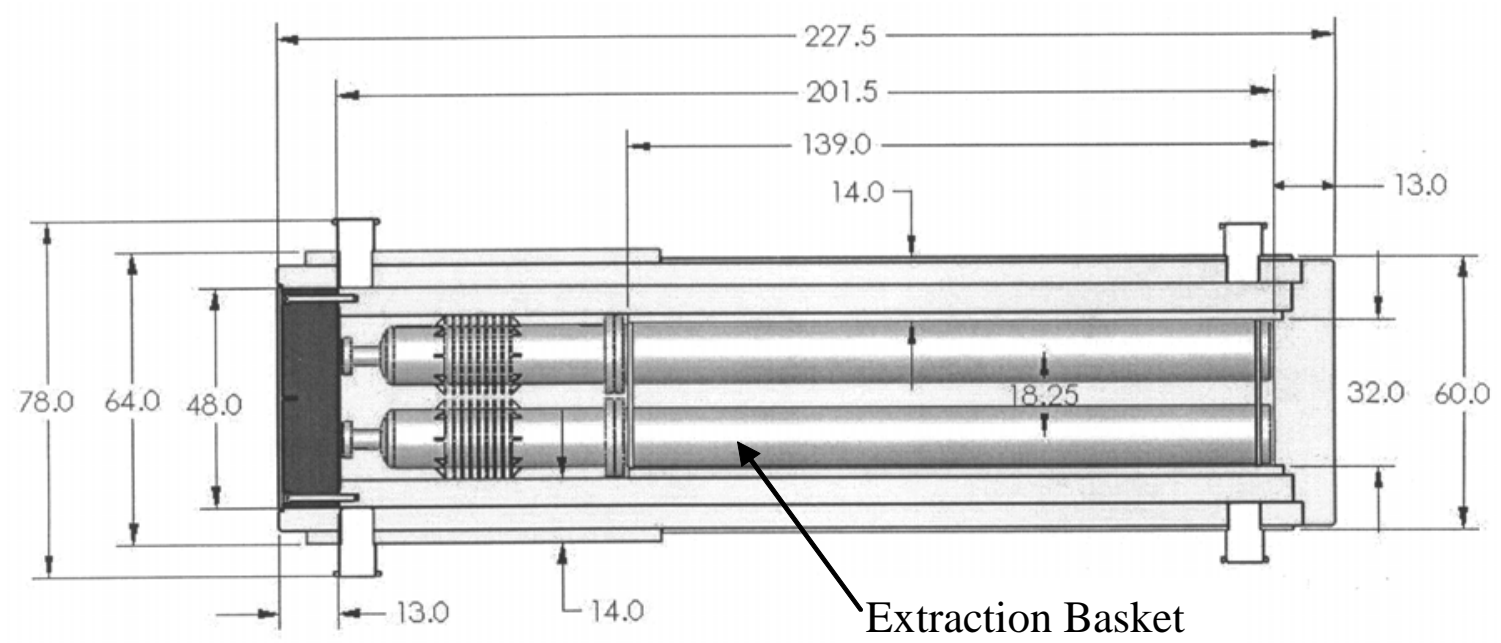

Figure 1 Sectional diagram of the TPBAR waste container (dimensions are in inches)

Inside the carbon steel outer wall, there are slots to place 4 extraction baskets, each designed to hold up to 300 extracted TPBARs. Each container will contain a maximum of 1200 extracted TPBARs. The containers will be placed within the ILV for final disposal, allowed to cool for a period of time and then encased in Consolidated Low Strength Material (CLSM) as the waste cell is filled.

Considerations related to placement of the containers within the ILV are discussed later in the report. 


\subsection{TPBAR WASTE CONTAINER RADIONUCLIDE INVENTORY}

The inventory of radionuclides contained in each TPBAR is presented in Pagh 2004, which identifies the radionuclide inventory for an "unextracted" TPBAR. While this source could be used to estimate the non-tritium radionuclide inventory for a fully-loaded waste container, in could not be used to quantify the tritium inventory. This is because most of the tritium is extracted from the TPBARs in the Tritium Extraction Facility (TEF) prior to loading the waste containers. The tritium inventory was based on a correspondence with the Defense Programs Project Startup team in an email from Brizes (see Brizes 2004). In this correspondence, the tritium inventory for a TPBAR immediately following extraction was reported to be $133 \mathrm{Ci}$ per TPBAR.

For calculating the non-tritium radionuclide content of a production TPBAR waste container four TPBAR bundles are assumed to be decayed for 180 days following irradiation. This assumption is conservative in that it represents the shortest time that four bundles of TPBARs might conceivably be ready for loading into a waste container. In reality, there will be pauses in production that cause the initial baskets to be stored temporarily until all 4 baskets are available to load into a waste container.

For both tritium and non-tritium radionuclides the inventory for a single TPBAR was multiplied by the maximum number of TPBARS that might be loaded into a waste container (1200) and then multiplied by the estimated 17 waste containers that are expected to be produced. The resulting radionuclide activity levels are reported in Table 1. 
WSRC-TR-2005-00531, Rev. 0

Table 1. Composite Radionuclide Inventory for 17 Production TPBAR Waste Containers.

\begin{tabular}{|c|c|c|c|c|c|}
\hline Nuclide & Activity, Ci & Nuclide & Activity, Ci & Nuclide & Activity, Ci \\
\hline Ar-37 & $2.51 \mathrm{E}+02$ & La-140 & $9.42 \mathrm{E}-07$ & Se-75 & $6.65 \mathrm{E}+03$ \\
\hline Ar-39 & $1.93 \mathrm{E}+02$ & Lu-177 & $1.59 \mathrm{E}-02$ & Sn-113 & $9.40 \mathrm{E}+03$ \\
\hline Ba-131 & $2.92 \mathrm{E}-02$ & Mn-54 & $5.81 \mathrm{E}+05$ & Sn-117m & $3.20 \mathrm{E}+01$ \\
\hline Ba-133 & $1.47 \mathrm{E}+01$ & Mo-93 & $2.12 \mathrm{E}+01$ & Sn-119m & $1.05 \mathrm{E}+05$ \\
\hline Ba-133m & $4.61 \mathrm{E}-33$ & Mo-99 & $3.96 \mathrm{E}-14$ & Sn-121m & $1.12 \mathrm{E}+01$ \\
\hline C-14 & $2.90 \mathrm{E}+01$ & Nb-92 & $4.65 \mathrm{E}-02$ & Sn-123 & $3.86 \mathrm{E}+03$ \\
\hline Ca-41 & $1.53 \mathrm{E}+00$ & Nb-93m & $1.25 \mathrm{E}-01$ & Sn-125 & $1.78 \mathrm{E}-01$ \\
\hline Ca-45 & $3.06 \mathrm{E}+03$ & Nb-94 & $9.71 \mathrm{E}+00$ & Sr-89 & $1.43 \mathrm{E}+02$ \\
\hline Ca-47 & $3.20 \mathrm{E}-12$ & Nb-95 & $4.06 \mathrm{E}+05$ & Ta-182 & $7.71 \mathrm{E}+04$ \\
\hline Cd-115 & $2.51 \mathrm{E}-23$ & Nb-95m & $1.53 \mathrm{E}+03$ & Ta-183 & $3.18 \mathrm{E}-05$ \\
\hline Cd-115m & $2.55 \mathrm{E}-01$ & Ni-59 & $3.43 \mathrm{E}+03$ & Tc-99 & $8.89 \mathrm{E}-01$ \\
\hline Co-58 & $1.01 \mathrm{E}+06$ & Ni-63 & $4.65 \mathrm{E}+05$ & Te-123m & $2.31 \mathrm{E}+01$ \\
\hline Co-60 & $6.90 \mathrm{E}+05$ & Ni-66 & $4.02 \mathrm{E}-23$ & Te-125m & $7.26 \mathrm{E}+05$ \\
\hline Cr-51 & $2.61 \mathrm{E}+05$ & Os-191 & $4.14 \mathrm{E}-04$ & W-181 & $4.47 \mathrm{E}+01$ \\
\hline Cs-131 & $1.50 \mathrm{E}-01$ & P-32 & $4.79 \mathrm{E}+00$ & W-185 & $8.61 \mathrm{E}+02$ \\
\hline Cu-66 & $4.02 \mathrm{E}-23$ & Re-186 & $1.05 \mathrm{E}-11$ & W-188 & $6.00 \mathrm{E}+01$ \\
\hline Fe-55 & $3.88 \mathrm{E}+06$ & Re188 & $6.06 \mathrm{E}+01$ & Y-89m & $1.30 \mathrm{E}-15$ \\
\hline Fe-59 & $2.82 \mathrm{E}+04$ & Ru-103 & $3.10 \mathrm{E}+00$ & Y-90 & $2.79 \mathrm{E}-02$ \\
\hline H-3* & $2.71 \mathrm{E}+06$ & S-35 & $7.18 \mathrm{E}+01$ & Y-91 & $5.04 \mathrm{E}+02$ \\
\hline Hf-175 & $1.20 \mathrm{E}+02$ & Sb-122 & $1.15 \mathrm{E}-16$ & Zn-65 & $5.14 \mathrm{E}+01$ \\
\hline Hf-181 & $1.06 \mathrm{E}+03$ & Sb-124 & $5.18 \mathrm{E}+01$ & Zr-89 & $1.31 \mathrm{E}-15$ \\
\hline In-113m & $9.42 \mathrm{E}+03$ & Sb-125 & $3.06 \mathrm{E}+04$ & Zr-93 & $2.31 \mathrm{E}+00$ \\
\hline In-114 & $2.28 \mathrm{E}+02$ & Sb-126 & $7.24 \mathrm{E}-02$ & Zr-95 & $2.06 \mathrm{E}+05$ \\
\hline In-114m & $2.39 \mathrm{E}+02$ & Sc-46 & $4.00 \mathrm{E}+01$ & & \\
\hline K-42 & $1.69 \mathrm{E}-07$ & Sc-47 & $4.04 \mathrm{E}-11$ & & \\
\hline
\end{tabular}

Note: Inventory based on 17X the inventory for a single TPBAR, reported in Pagh, 2004.

Note: The composite inventory for non-tritium radionuclides is calculated for 180 days following irradiation.

Note: The following nuclides were present in the TPBAR immediately following irradiation but had decayed to zero by 180 days following irradiation: As-76, Ba-135m, Br-82, Cu-64, Na-24, Nb-96, Nb-97, Nb-97m, Sn-121, W-187, Zr-97.

* Tritium inventory is based on an extracted TPBAR, 133 Ci/TPBAR as described in Brizes, 2004. 
WSRC-TR-2005-00531, Rev. 0

\subsection{ILV DISPOSAL CONSIDERATIONS}

\section{Container durability}

The durability of the TPBAR waste containers within the disposal environment impacts the ability of its radionuclide contents to migrate out of the ILV and contribute to a potential human exposure through one of the defined pathways. For non-tritium radionuclides such mobility cannot occur until the outer wall of the TPBAR waste container fails, either mechanically or chemically, as by corrosion. Hydrogen, on the other hand, has the ability to diffuse readily through metals. This ability of hydrogen (i.e., tritium) and other elements to diffuse in metals at room temperatures has been extensively investigated. One source is cited herein, Nowick and Burton 1975, in which the relative rate of diffusion is established for hydrogen versus other interstitial elements (e.g., oxygen, nitrogen, carbon). The difference is noted to be 15-20 orders of magnitude higher for hydrogen than the other elements. Data from this resource confirms the inability of non-hydrogen elements to escape the TPBAR container by diffusion prior to penetration of the waste container's exterior wall.

There is considerable mechanical strength to the TPBAR waste container owing to its 13-inch thick, carbon-steel exterior walls, in addition to the strength afforded by the grout-like Consolidated Low Strength Material (CLSM) surrounding the container in the ILV disposal configuration. Given the robust construction design of the TPBAR container, the chief mechanism of failure potentially leading to release of its radionuclide inventory is likely to be corrosion of the container walls and welds.

An analysis was conducted to evaluate both localized and general corrosion of the first TPBAR waste container when placed within the ILV disposal environment and is documented in Vinson. et. al., 2004. In that investigation, corrosion processes were evaluated at the exterior surface of the TPBAR container where it comes into contact with the CLSM, and inside the TPBAR waste container where the vapor comes into contact with the inner wall.

With respect to the exterior surface, the penetration time for a 0.5 -inch weld (i.e., one-half the weld thickness of the TPBAR waste containers) was calculated to be approximately 12,600 years based on the $1 \mathrm{um}$ /year rate of general corrosion reported for the high-pH conditions of the ILV disposal environment (Vinson, 2004). With respect to corrosion of carbon steel inside the container, the total metal loss from general corrosion was calculated to be insignificant (Vinson, 2004). This determination has an important implication for this investigation. All radionuclides, with the exception of tritium, will be bound within the TPBAR containers for the full 1000-year PA compliance period. None of these will be able to contribute to a potential human exposure along any of the PA-defined exposure pathways that depend on radionuclide migration from the waste (i.e., air and groundwater). As a result, there is no need to calculate disposal limits for these radionuclides for the 17 expected TPBAR waste containers via the air and groundwater pathways. Tritium will be able to escape the TPBAR containers, by diffusion through the carbon-steel walls, hence it is evaluated in further detail.

\section{Heat buildup and associated facility loading concerns}

There are two main concerns related to the heat buildup within the ILV if 17 production TPBAR waste containers are ultimately disposed within it, these are: 1) whether the initial curing of CLSM 
WSRC-TR-2005-00531, Rev. 0

used to encapsulate the containers might be impacted and 2) whether temperatures might exceed $430{ }^{\circ} \mathrm{F}$ within the grout-like encapsulating material.

Proper curing of CLSM could be jeopardized if the waste container walls approaches the boiling point of water $\left(212^{\circ} \mathrm{F}\right)$ during the period when it solidifies, which occurs within the first 24 hours of emplacement of the CLSM slurry (verbal communication with Don Sink, Waste Management Area Project). It has also been noted (Vinson, 2004) that the calcium hydroxide reaction within grout-like materials at temperatures $>430^{\circ} \mathrm{F}$ could result in spalling and thus reduce the structural integrity of the system. To avoid the possibilities of these undesirable situations occurring, a recommendation was made in Vinson 2004 that the temperature of the TPBAR container wall remain $<203{ }^{\circ} \mathrm{F}$ during the period when the CLSM slurry is solidifying and that the temperature in concrete and CLSM remain below a service temperature of $400^{\mathrm{C}}$.

Both of these concerns were addressed in the heat analysis conducted to support the SA that evaluated disposal of the initial TPBAR waste container within the ILV. The heat buildup determined in that investigation (Vinson, 2004) did not cause either of the 2 limiting conditions to be approached. This SA differs in that it evaluates the placement of multiple TPBAR waste containers within individual ILV cells and hence the same concerns must be considered.

To evaluate the potential for exceeding the critical temperature requirements if multiple containers are placed within the ILV, the findings of the two relevant heat analyses of TPBAR waste containers must be reviewed.

The first heat analysis was for a single TPBAR waste container embedded in the center of a fully grouted ILV cell (Vinson, 2004). In this investigation the heat buildup resulting from an initial thermal load of 2,458.4 Btu/hr (720 watts) was calculated using a 2-D, cross-sectional numerical heat flow model. In addition, a solar heat source of $1.71 \mathrm{Btu} / \mathrm{h}-\mathrm{in}^{2}$ was applied to the upper horizontal surface and solar heat source of $0.43 \mathrm{Btu} / \mathrm{h}-\mathrm{in}^{2}$ was applied to the vertical side surfaces.

Using a set of conservative assumptions, the highest steady-state temperature was calculated to reach $200^{\circ} \mathrm{F}$ in the center of the TPBAR container while the highest temperature at the inner surface of the exterior wall was calculated to be $175^{\circ} \mathrm{F}$. The resulting heat field for the fully grouted cell is illustrated in Figure 2, in which the TPBAR container was positioned in the lower portion of the 44foot long cell. The height of the cell is approximately 26 feet. 
WSRC-TR-2005-00531, Rev. 0

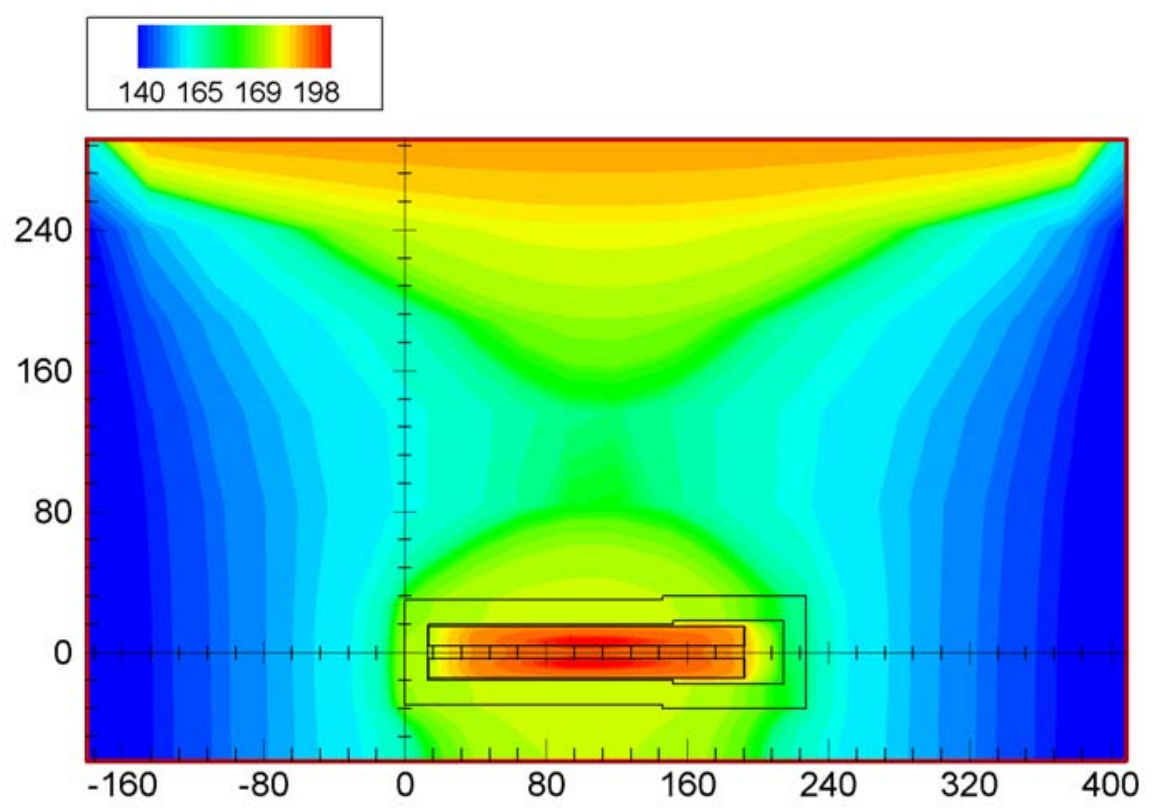

Figure 2 Heat field for TPBAR container fully encased in grout (units in ${ }^{\circ} \mathrm{F}$ )

The boundary conditions incorporated into this heat flow model were admittedly conservative, and resulted in a higher temperature distribution than is actually expected to actually occur when TPBARs are loaded into the ILV. These conditions are discussed below:

1. The TPBAR container was encased in a fully grouted ILV cell.

In actuality, ILV cells are gradually filled with waste material, the material being placed in successive layers approximately 4-4.5 ft. deep before each is filled over with CLSM slurry. There is a period of one or more years between slurry pours, during which time another layer of waste material is placed on the new floor formed by the previous pour. The initial CLSM slurry pour will not cover the top of the TPBAR waste container, hence there is expected to be an extended period when heat can dissipate directly from the waste container into the overlying air-space. The heat source term, itself, dissipates with time due to radioactive decay, as the cell is gradually filled. Hence, as the overlying grout layer thickens, the heat source term diminishes.

Additionally, the actual fill material is a combination of waste material (including metal B-25 boxes) and CLSM, which is likely to have a significantly higher heat conductance than that of the solid grout material, which was used in the heat flow model. The higher heat conductance of the fill material would allow for more rapid heat dissipation to the overlying air space and the sides of the cells.

2. The external environment of the ILV cell was represented having an ambient temperature of $100^{\circ} \mathrm{F}$.

Information from numerous sources indicate that the environmental temperature surrounding the ILV (i.e. the air and soil) have temperatures that vary seasonally and have mean values significantly lower than the assumed $100^{\circ} \mathrm{F}$. One source is a SRNL Calculation Cover Sheet, M-CLC-A-00226, Transient Foundation Temperatures below a Saltstone Vault with Sloped Walls. In this report the soil 
seasonal temperature characteristics are indicated, ranging from $49^{\circ} \mathrm{F}$ to $72{ }^{\circ} \mathrm{F}$ from January to July at depths of $<1 \mathrm{~m}$, and having a mean of $\sim 62^{\circ} \mathrm{F}$. At depths $>6 \mathrm{~m}$ the soil temperature is a constant $62^{\circ} \mathrm{F}$ and is unaffected by seasonal air temperature variation. This is consistent with information from the NOAA-CIRES/Climate Diagnostics Center, which reports that the composite annual mean air temperature for the vicinity of the SRS is in the $60^{\circ} \mathrm{F}$ to $62^{\circ} \mathrm{F}$ range based on measurements acquired from 1950 to 1995 . This suggests how conservative the assumption of $100^{\circ} \mathrm{F}$ for the environment immediately surrounding the ILV cell in the Vinson, 2004 model actually is, especially considering that it is a steady-state model.

3. A continuous heat source term resulting from solar heating along the upper and side surfaces of the grout material in the model domain was applied to those surfaces.

While solar heating along the vertical sides of the ILV will actually occur as the production TPBARs are loaded into the ILV, there is a roof above the facility which prevents sunlight from reaching the upper surface of the uppermost CLSM layer as the cells are gradually filled. In addition, the air-space between the CLSM and the roof is vented by a 4 to 6 inch gap that allows for air circulation to occur and therefore would likely keep the air-space temperature very close to the ambient (outside) air temperature.

\section{Base of model was represented as a no-flow heat boundary.}

The annual mean soil temperature is likely to be very similar to the composite annual mean air temperature. Therefore, it would appear likely that there would actually be a significant heat loss through the base of the ILV cell.

Considering the combined effect of all 4 conservative measures listed above, it is likely that the actual heat field around a production TPBAR container embedded at one of the lower corners of the ILV cell would be significantly lower across most of the domain than is shown in Figure 2, and probably significantly lower than the minimum scale temperature of $140^{\circ} \mathrm{F}$ in that illustration.

The second heat analysis was for a production TPBAR waste container sitting outside on a pad for a period of 5 years. The purpose of that study was to calculate the peak internal temperature and outer container wall temperatures and is documented in Vinson, 2005. To determine the temperature profiles of the waste container through time, 11 steady-state, 2-D numerical simulations were performed for specific times over a 5-year period. Each successive simulation used the reduced heat source term calculated for each of 11 successive times following the completion or irradiation (see Pagh, 2004). The rate of decline in source term for a waste container loaded with 1200 TPBARs is illustrated in Figure 3 as are the results of the heat simulations. 
WSRC-TR-2005-00531, Rev. 0

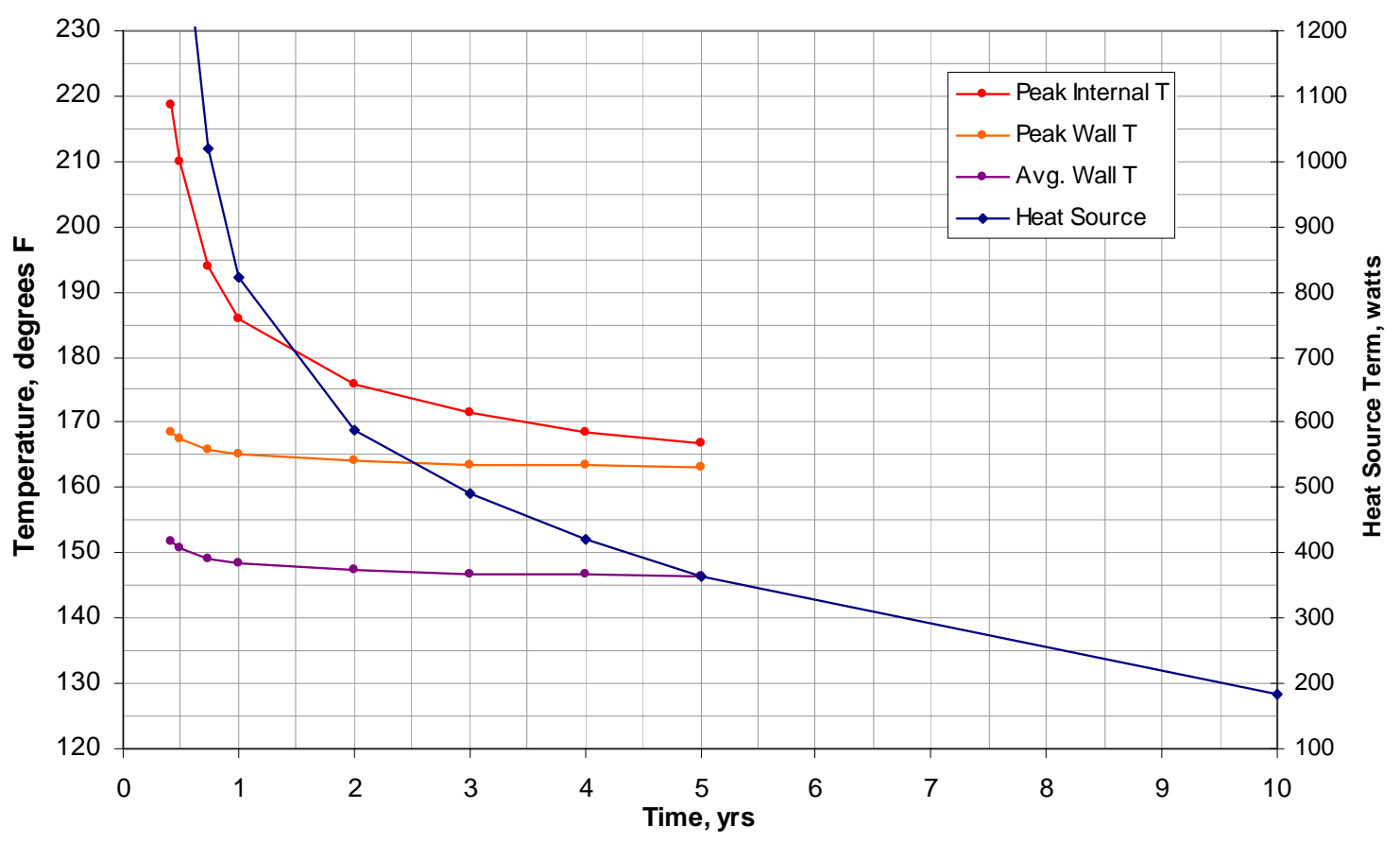

Figure 3 Waste container temperature profiles and heat source term for 1200 TPBARs

While the peak internal temperature appears to decline in a fashion related to the decline in the heat source term the waste container wall temperatures decline much more gradually and appear to approach a near-constant temperature. The reason for this is the boundary conditions imposed on the model domain. Primarily, these include heat source terms applied to the upper and side walls of the waste container (driven by solar heating) and the assumption that the temperature of the ambient environment surrounding the waste container is $100^{\circ} \mathrm{F}$.

The boundary conditions incorporated into this model, as was the case with the first heat analysis, were admittedly conservative. While the application of a heat source term on the upper horizontal and the side vertical walls is appropriate for this simulation, the assumption of an ambient environmental temperature of $100{ }^{\circ} \mathrm{F}$ is much higher than the composite annual mean air temperature of $\sim 60^{\circ} \mathrm{F}$ for the SRS, and is therefore regarded as an unreasonable representation. Also, a "no-flow" heat boundary condition was imposed on the bottom edge of the model domain such that heat could not be lost to the underlying soil.

Despite the highly conservative nature of the two heat simulations, they can be used as a guide to demonstrate that if managed prudently, all of the 17 production TPBAR waste containers can be loaded into the ILV without temperatures approaching the critical temperatures of $205^{\circ} \mathrm{F}$ in the first 24 hours of encapsulation or $400^{\circ} \mathrm{F}$ at any time after that. The specific concerns are addressed below.

1) Might the initial curing of CLSM used to encapsulate the containers be impacted?

A TPBAR container will be allowed to sit within an ILV cell for a long-enough time that the heat source term declines to a maximum of 720 watts (the heat load of the initial heat analysis) before it is covered with CLSM slurry. Since the waste container will be sitting in open air, without a 
WSRC-TR-2005-00531, Rev. 0

solar heat source on the sides or top, the wall temperature will be lower than the wall temperature determined in the second heat analysis. From that analysis the wall temperatures associated with a thermal load of 720 watts can be estimated. At that heat load, the maximum and average wall temperatures were calculated to be $166^{\circ} \mathrm{F}$ and $148^{\circ} \mathrm{F}$, respectively, while the peak internal temperature was calculated to be approximately $182^{\circ} \mathrm{F}$. It is not likely that the waste container wall temperature will rise more than a few degrees within the first 24 hour period when curing occurs, especially since the temperature of the slurry is likely to be considerably less than $100{ }^{\circ} \mathrm{F}$. In fact, the temperature of the container walls will likely remain very close to the slurry temperature over this time period.

2) Might the temperatures exceed $430{ }^{\circ} \mathrm{F}$ anywhere within the ILV due to the placement of multiple production TPBAR containers (17) within it?

If prudent management of the placement of the TPBAR waste containers within the ILV is applied, it is unlikely that temperatures within the ILV will come close to approaching the $430{ }^{\circ} \mathrm{F}$ criteria required to maintain grout material structural integrity. Furthermore, it is unlikely that temperatures will elevate to the point where there will be any interference with adjacent waste packages.

Prudent management measures to minimize the heat buildup within the ILV include the following:

- Utilization of all available cells within the ILV (7) to maximize the lateral distance between TPBAR waste containers as they are placed within the ILV after arriving from the TEF.

- Allowance for at least 1.5-year of cooling time for each TPBAR waste container following irradiation at the TVA reactor before encasement in CLSM. This would permit the heat load of each container to dissipate to that utilized within the initial heat analysis (Vinson, 2004).

- Placement of TPBAR containers in a horizontal position parallel to and close to the outer walls of cells. This configuration would maximize dissipation of heat, not only to the airspace immediately above the container prior to CLSM encasement, but also to the side wall after CLSM encasement.

- Use of a "double-stacking” arrangement of TPBAR waste containers along the outside edges of individual ILV cells. If there is metal-to-metal contact of waste containers, they will act as single unit, thermally, and will maximize the length of time that at least one side of the waste container unit is in contact with the overlying air space. Such contact will maximize the dissipation of heat.

- Periodic monitoring of CLSM temperature within the ILV, especially as adjacent cells have waste containers placed within them, would be useful to verify that the critical temperature ( $400^{\circ} \mathrm{F}$ ) is not being approached.

The key facts that suggest that prudent management of container placement will control excessive heat buildup are the following:

- There will be a staggered arrival schedule of TPBAR containers from the TEF stretching out for approximately 15 years, see Table 2 . This table is presented to assist operations managers in the process of evaluating plans for specific cell loading arrangements.

- The heat load of each individual TPBAR container dissipates relatively rapidly through time, as shown in Figure 3.

- The highly conservative nature of the previous heat analyses, particularly the assumption that the temperature of the surrounding environment is a constant $100^{\circ} \mathrm{F}$ (sides, top and base). 
- The presence of ventilated air-space above the TPBAR containers, before and after encasement with CLSM.

- Removal of the upper surface heat source from solar shine due to the presence of a roof. Note that in Figure 2 the heat field would be considerably reduced if the solar heat source were removed.

Table 2. The staggered arrival schedule of TPBAR waste containers

\begin{tabular}{|c|c|c|}
\hline $\begin{array}{l}\text { TPBAR } \\
\text { Container } \\
\text { Number }\end{array}$ & $\begin{array}{l}\text { Approximate Date of } \\
\text { Transport from TEF }\end{array}$ & $\begin{array}{c}\text { Date Heat Source } \\
\text { Dissipates to } \\
720 \text { Watts }\end{array}$ \\
\hline 1 & Jul-08 & Jul-08* \\
\hline 2 & Jun-11 & Jun-12 \\
\hline 3 & Jan-13 & Jan-14 \\
\hline 4 & Jan-14 & Jan-15 \\
\hline 5 & Aug-14 & Aug-15 \\
\hline 6 & Aug-15 & Aug-16 \\
\hline 7 & Feb-16 & Feb-17 \\
\hline 8 & Feb-17 & Feb-18 \\
\hline 9 & Aug-17 & Aug-18 \\
\hline 10 & Aug-18 & Aug-19 \\
\hline 11 & Jan-19 & Jan-20 \\
\hline 12 & Jan-20 & Jan-21 \\
\hline 13 & Jul-20 & Jul-21 \\
\hline 14 & Jul-21 & Jul-22 \\
\hline 15 & Jan-22 & Jan-23 \\
\hline 16 & Jan-23 & Jan-24 \\
\hline 17 & Jan-23 & Jan-24 \\
\hline
\end{tabular}

Note: Adapted from schedule identified 9/27/05 Program Managers Briefing.

* No requirement to wait 1.5 years after irradiation before encasing with CLSM

An additional loading consideration is a suggestion that the waste container trunions be kept slightly away from direct contact with the outer wall material such that CLSM is able to form intimate contact with the entire container. This would create a 10-12 inch space for CLSM to fill in between the container and cell wall and therefore to maintain an environment consistent with that described in the corrosion analysis (Vinson, 2004). 


\subsection{TRITIUM RELEASE FROM A PRODUCTION TPBAR CONTAINER}

Tritium will not be isolated within the TPBAR waste container like the other radionuclides in the because of its propensity to diffuse through the exterior walls. Due to this characteristic, further consideration must be given to the rate of permeation through the TPBAR container walls and the potential release of tritium via the air and groundwater pathways.

A classified estimate of the permeation rate of tritium through the TPBAR waste container was made by investigators at PNNL. Consideration was given to the construction details of the waste containers and a temperature of $175^{\circ} \mathrm{F}$ was assumed, based on the peak container wall temperature calculated in Vinson, 2004. To facilitate unclassified analyses, PNNL also produced a bounding unclassified estimate of the tritium permeation rate through the walls of a typical TPBAR waste container for use in this SA (Reid, 2005). That permeation rate is presented in Table 3.

Table 3 PNNL unclassified release rate from a fully loaded TPBAR container

\begin{tabular}{|c|c|}
\hline Year & Tritium Release Rate \\
\hline & (Ci/year) \\
\hline 0 & 0 \\
\hline 1 & 1160 \\
\hline 2 & 1740 \\
\hline 3 & 2090 \\
\hline 3.5 & 2210 \\
\hline 5 & 2210 \\
\hline 10 & 2210 \\
\hline 15 & 2210 \\
\hline 20 & 2210 \\
\hline 25 & 2210 \\
\hline 26 & $2.0 \mathrm{E}-5$ \\
\hline
\end{tabular}




\subsection{ANALYSES}

Tritium is the only radionuclide that can escape the TPBAR waste container within the 1000-year PA compliance period. Tritium is also relatively mobile within the subsurface environment and hence could cause human exposure through either the air or groundwater pathways. As a result, both of these pathways must be evaluated for tritium.

In addition to these analyses, the resident intruder pathway is evaluated since, theoretically, radiation can emanate from all radionuclides within the TPBAR waste container and could cause an exposure to the resident intruder.

\subsection{AIR AND RADON PATHWAY ANALYSES}

The air pathway is of limited significance for the TPBAR waste container since the thick steel walls prevent the release of all radionuclides, with the exception of tritium, over the 1000-year PA compliance period. For this reason, C-14 is not considered in the air pathway analysis despite an initial activity level that suggests it could contribute a significant fraction. It should also be pointed out that even if $\mathrm{C}-14$ were to escape the TPBAR waste container it would partition in the solid phase as ${ }^{14} \mathrm{CO}_{3}$ within the ILV disposal environment, as has been documented in Kaplan, 2005. Tritium can permeate the TPBAR waste container and potentially escape the vault and result in an exposure, hence an air pathway evaluation is provided for that radionuclide.

The air release is calculated at two exposure points, at the SRS boundary during the period of institutional control and at $100 \mathrm{~m}$ from the ILV after the loss of institutional control. The analyses below are performed for both exposure locations.

\subsubsection{SRS Boundary Analysis}

The calculations for the SRS boundary used the following constants, obtained from Flach and Hiergesell 2004:

Exposure limit $=10 \mathrm{mrem} / \mathrm{yr}$

Dose factor $=2.4 \mathrm{E}-06 \mathrm{mrem} / \mathrm{Ci}$

Release fraction $=3.2 \mathrm{E}-04$

The maximum annual permeation from all 17 of the TPBAR container is calculated to be $3.76 \mathrm{E}+04$ $\mathrm{Ci} /$ year (i.e. peak tritium emanation rate $2210 \mathrm{Ci} / \mathrm{yr}$ * 17 containers), hence this is the rate that should be used to determine the exposure that could result from disposing all the production TPBAR containers simultaneously in the ILV. From this information:

Air release $=$ Maximum release rate * Air Release Fraction $=(3.76 \mathrm{E}+04 \mathrm{Ci} / \mathrm{yr}) * .3.2 \mathrm{E}-04=$ $1.2 \mathrm{E}+01 \mathrm{Ci} / \mathrm{yr}$

This is converted to a human exposure as follows:

1.2E+01 Ci/year released * 2.4E-06 mrem/Ci $=2.89 \mathrm{E}-05 \mathrm{mrem} / \mathrm{yr}$. 
This exposure represents only a small fraction of the human exposure limit, $10 \mathrm{mrem} / \mathrm{year}$, which is calculated as follows:

Fraction of exposure limit $=(2.89 \mathrm{E}-05 \mathrm{mrem} / \mathrm{yr}) /.(10 \mathrm{mrem} / \mathrm{yr})=.2.89 \mathrm{E}-06$

This fraction is used to back calculate the maximum number of $\mathrm{Ci}$ of tritium that might be disposed within all TPBAR containers as follows:

Total TPBAR container (17) tritium limit = 2.71E+06 Ci * $(10 \mathrm{mrem} / \mathrm{yr} . / 2.89 \mathrm{E}-05 \mathrm{mrem} / \mathrm{yr})=$. $9.40 \mathrm{E}+11 \mathrm{Ci}$

The fraction of this limit that the initial TPBAR container inventory consumes is equivalent to the exposure fraction and is calculated as follows:

Fraction of disposal limit $=2.71 \mathrm{E}+06 \mathrm{Ci} / 9.40 \mathrm{E}+11 \mathrm{Ci}=2.89 \mathrm{E}-06$

\subsection{2 $100 \mathrm{~m}$ Analysis}

Calculation of the total TPBAR containers (17) limit at the 100-m compliance point can be evaluated using the different ILV tritium air pathway limits determined for each exposure location, in Flach and Hiergesell 2004. These limits were determined to be $1.3 \mathrm{E}+10 \mathrm{Ci}$ and $1.3 \mathrm{E}+09 \mathrm{Ci}$ for the SRS boundary and $100 \mathrm{~m}$ exposure points, respectively.

Since the disposal limit is 1 order of magnitude lower when the analysis is performed $100 \mathrm{~m}$ from the ILV, the total TPBAR container limit at the $100 \mathrm{~m}$ compliance point is therefore an order of magnitude lower than is calculated for the SRS boundary. This limit is $9.40 \mathrm{E}+10 \mathrm{Ci}$. Accordingly, the fraction that the total TPBAR containers (17) inventory represents is calculated to be $2.71 \mathrm{E}+06 \mathrm{Ci}$ / 9.40E+10 Ci = 2.89E-05.

The radon pathway is of no significance in this SA because there is no possibility of a human exposure to radon (Rn-222) occurring as a result of the proposed disposal action. There are no parent radionuclides of $\mathrm{Rn}-222$ present in the inventory being disposed within the TPBAR waste containers. Thus, a Rn-222 limit of $>1.0 \mathrm{E}+20 \mathrm{Ci}$ is established specifically for the 17-container waste package.

\subsection{RESIDENT (INTRUDER) PATHWAY ANALYSIS}

New resident limits specifically for this waste package were not calculated. An automated resident pathway analysis was conducted in Flach and Hiergesell 2004 to establish new ILV disposal limits. Examining the composite inventory summarized in Table 1, with respect to these limits, indicates the fractions for each radionuclide that is associated with generic ILV waste. The greatest fractions are for Co-60 and Nb-94 and are calculated to be 8.62E-04 and 7.47E-04, respectively. The other radionuclides' fractions are all much, much less (i.e., the next largest fraction is 8.64E-09 for Ba133). As a result, there are no radionuclides associated with the TPBAR waste container that pose a threat to the resident intruder. 
WSRC-TR-2005-00531, Rev. 0

\subsection{GROUNDWATER PATHWAY ANALYSIS}

The groundwater pathway analysis was based on the analysis described in Flach and Hiergesell 2004. That report computed new disposal limits for the ILV disposal unit based upon several changes to the original E-Area Performance Assessment (PA). The most important change evaluated in that study was the implementation of a 1,000-year time of compliance compared to a 10,000-year period for the PA. Other revisions to the original PA included: refinement of the groundwater model mesh to allow a more precise incorporation of the IL vault footprints, a new Pu chemistry model accounting for incorporation of different transport properties of oxidation states III/IV and V/VI, and the implementation of a timed sum-of-fractions approach to setting disposal limits. In this SA, the groundwater model developed in Flach and Hiergesell 2004 was modified to evaluate the tritium flux introduced into the ILV by the production TPBAR waste containers.

The tritium source term was handled differently than it was in Flach and Hiergesell 2004 because the TPBAR containers have much smaller volumetric dimensions than the ILV, for which tritium limits were originally calculated. The highly compact placement of the tritium source term within the ILV could produce higher concentrations at the 100-meter compliance well than what would be produced from a uniformly distributed placement throughout the ILV. Consequently, the evaluation was performed to determine the groundwater pathway under this condition, where specific placement of the individual containers is accounted for.

As in Flach and Hiergesell 2004, separate simulations were conducted for the vadose zone and the saturated (groundwater) zone. The vadose zone model takes advantage of symmetry by only simulating $1 / 2$ of the ILV disposal unit, in cross-section. No ILV cell will contain more than 4 TPBAR containers which will be placed in stacks of 2 near the outer walls of the cell. Hence, to be consistent with the symmetry approach, only 2 TPBAR containers were placed into the model domain and were situated in a position close to both the base of the ILV and the outer wall. This configuration is justified because such positioning is likely to produce a higher tritium concentration at the 100-meter compliance well. Material properties were altered so as to make the TPBAR containers virtually impermeable and new steady-state flow fields were simulated for each of the relevant time periods. The vadose zone model construction reflects the geometry of the current E-Area closure plan and separate flow fields were established for the different configurations and infiltration rates associated with operation, institutional control and final closure of the ILV facility. Individual flow fields corresponded to the time-periods 0-25 years, 25-125 years, 125-325 years and 325 to 575 years. Time zero is the start of disposal unit operation.

Tritium was the only contaminant simulated in the transport simulations because it is the only radionuclide that can escape the TPBAR containers within the 1000-year PA compliance period. The half-life of tritium is sufficiently short that the fluxes passing from the vadose zone to the groundwater zone and concentrations in the 100-meter compliance well are both well past their respective peaks by 575 years. Consequently, it was not necessary to continue the simulation for time periods beyond that time frame as was done in the simulations described in Flach and Hiergesell 2004. Next, the tritium source term was introduced within a "halo" zone surrounding the TPBAR containers to mimic the release of tritium by permeation through the exterior walls of the containers and transport of tritium was simulated with respect to time. The tritium source term was based on the PNNL unclassified calculation of tritium permeation through an individual TPBAR container, and doubled to accurately reflect the combined rate for 2 TPBAR containers, as represented in the model.

The results of this simulation are shown in Figure 4 and 5. In Figure the tritium concentration distribution in the vadose zone is illustrated at a time 100 years following placement of the TPBAR 
containers within the ILV. The small black rectangle represents the end-view of 2 TPBAR containers stacked one upon the other within the ILV, while the surrounding colors represent tritium concentrations in $\mathrm{pCi} / \mathrm{L}$.

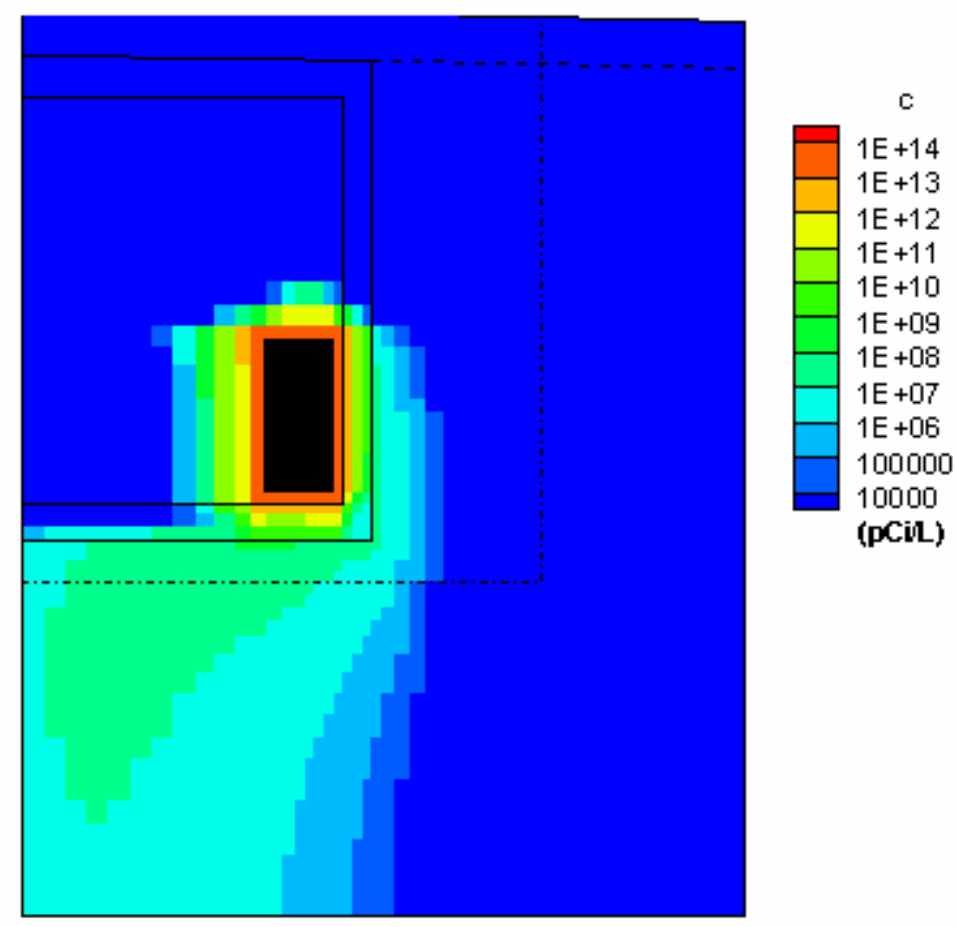

\section{Figure 4 Tritium concentration in vadose zone at 100 years}

The total flux leaving the vadose zone with respect to time is presented in Figure 5 . In this graph tritium flux rapidly increases, reaching a peak of 2.67E-05 Ci /year at about 94.3 years after which it begins a steady decline to $1.75 \mathrm{E}-14 \mathrm{Ci} /$ year at the end of the simulation (575 years). A slight decrease in the flux curve is noted between 125 and 325 years, which is attributable to the placement of the final closure cap (at year 125) over the ILV and surrounding soil and the accompanying decrease in infiltration into the soil immediately surrounding the ILV. The closure cap is assumed to degrade significantly after 325 years, resulting in increased infiltration to the soil, thus there is a small increase in the flux curve after 325 years. After 575 years the closure cap over the ILV is assumed to fail and infiltration at the land surface will revert to $40 \mathrm{~cm} / \mathrm{yr}$. This may cause a flushing of any remaining tritium in the ILV and eventually result in a small peak in the groundwater concentration. The residual tritium at that time is calculated to be $1.79 \mathrm{E}-09 \mathrm{Ci}$ which is very small compared to the maximum tritium flux from the vadose zone to the aquifer $(2.67 \mathrm{E}-05 \mathrm{Ci} / \mathrm{yr})$. Any resulting peak at the $100 \mathrm{~m}$ well after 575 years will therefore be less than the peak observed at the 100-meter well shortly after the maximum flux to the aquifer is realized.

The flux output from the vadose zone model was multiplied by the appropriate factor such that it represented the flux from all 17 TPBAR waste containers (which would reside in 5 different ILV cells) and applied as input to the groundwater (saturated zone) model. This flux was applied to four groundwater model elements immediately below the ILV in rates that varied in 0.1-year increments. 
WSRC-TR-2005-00531, Rev. 0

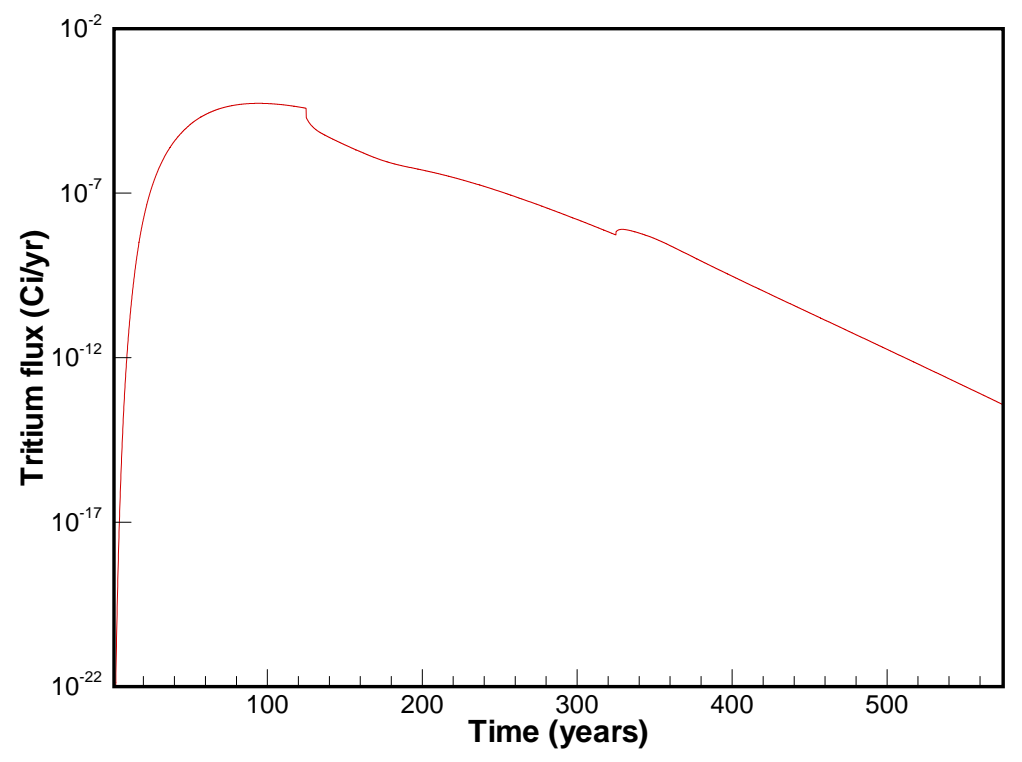

Figure 5. Tritium flux at lower boundary of Vadose Zone model

The groundwater (or saturated zone) model utilized in this SA is essentially the same one developed and described in Flach and Hiergesell 2004. A few minor adaptations of the previous model were implemented to accommodate specific needs for this investigation, including limiting the simulation period to 575 years and restricting the element(s) within which tritium flux from the vadose zone was introduced.

The tritium groundwater concentrations at a position 100 meters down gradient from the ILV were tracked and are presented in Figure 6. To identify the location where the peak groundwater concentration occurs with respect to time, a "wall" of elements was identified to record concentration histories. The concentration history for the element at which the peak concentration occurs is what appears in Figure 6. The tritium concentration at the location of this element begins to increase significantly after 40 years and continues this trend until a peak of $27.9 \mathrm{pCi} / \mathrm{L}$ is reached at 99 years. After this, the tritium groundwater concentration decreases at a similar rate until it approaches zero after 200 years. The overall peak concentration occurs at 99 years, which is within the time period used to calculate the GW1 disposal limit (0-100 years). For the period used to calculate the GW2 disposal limit, 100-1350 years, the maximum groundwater concentration occurs in year 101, immediately after the time boundary defined for the two limits. As expected, the peak groundwater concentration in this time period, $27.8 \mathrm{pCi} / \mathrm{L}$, is nearly identical to the peak realized in the earlier time period 27.9 pCi/L. Hence, disposal limits calculated for GW1 and GW2 are nearly identical, but not exactly the same. 


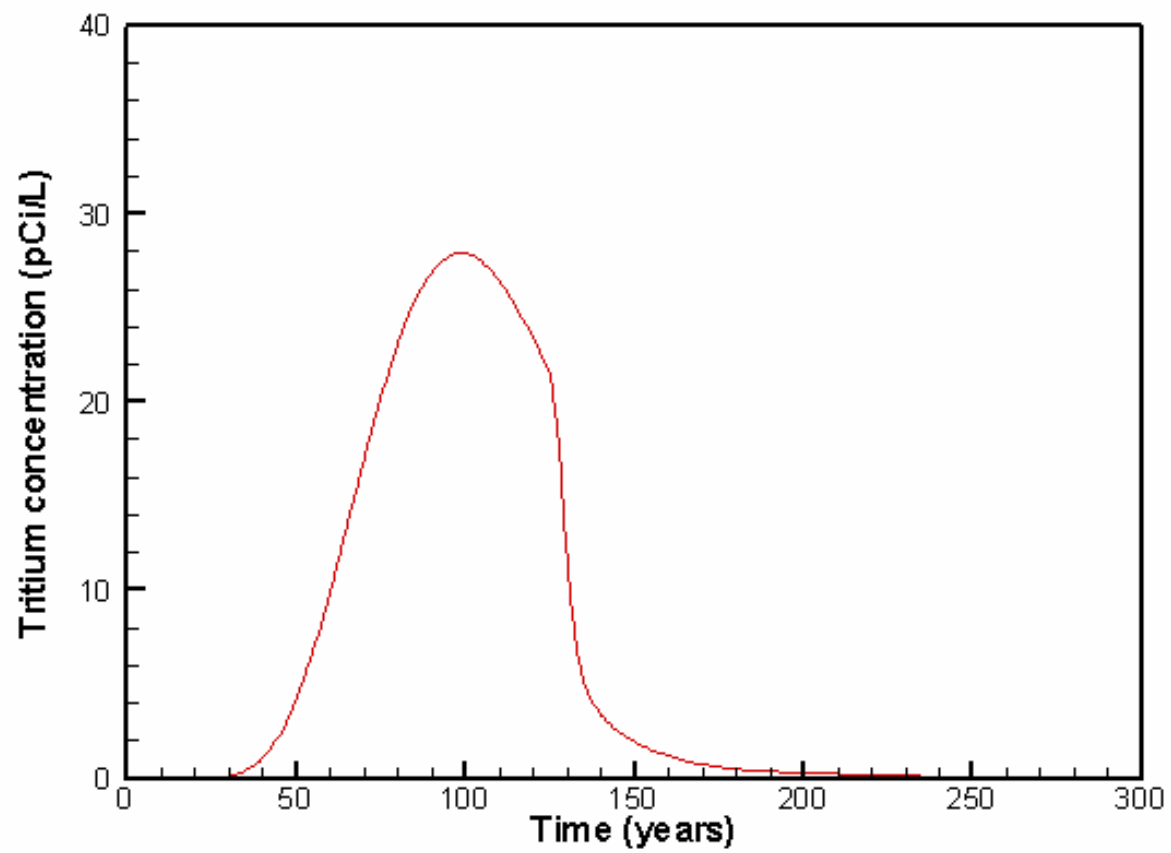

Figure 6. Tritium concentration at the 100 meter compliance point

The peak groundwater tritium concentration realized at the 100-meter compliance well as a result of disposing the TPBAR container in the ILV represents only a small fraction of the MCL of 20,000 $\mathrm{pCi} / \mathrm{L}$. That fraction of the MCL is calculated to be $(27.9 / 20,000)$ or $1.40 \mathrm{E}-3$.

Using the peak tritium groundwater concentration at the compliance point, the maximum tritium activity that could be introduced into the 17 TPBAR containers without exceeding the MCL (i.e., the inventory limit) is calculated using the following relationship.

$$
\frac{(27.9)}{(20,000)}=\frac{(2.71 E+06)}{(X)} \quad \text { or } \quad X=1.94 E+09 C i
$$

The fraction that the TPBAR container's actual tritium inventory represents of this calculated container limit is therefore:

$$
\frac{2.71 E+06 C i}{1.94 E+09 C i}=1.40 E-03
$$

This fraction is applicable to the GW1 time period since the overall peak tritium groundwater concentration occurs at 99 years, which is within the (0-100) year time period.

Similarly, for the GW2 time period (100-1350 years) the maximum groundwater tritium concentration is a very small fraction of the MCL. This fraction of the MCL is calculated to be $(27.8 / 20,000)$ or $1.39 \mathrm{E}-03$. 
For the GW2 time period, using the maximum tritium groundwater concentration at the compliance point, the maximum tritium activity that could be introduced into the TPBAR container without exceeding the MCL (i.e., the inventory limit) is calculated using the following relationship.

$$
\frac{(27.8)}{(20,000)}=\frac{(2.71 E+06)}{(X)} \quad \text { or } \quad X=1.95 E+09 C i
$$

The fraction that the TPBAR container's actual tritium inventory (non-LTA) represents of this calculated container limit is therefore:

$$
\frac{2.71 E+06 C i}{1.95 E+09 C i}=1.39 E-03
$$

This is the TPBAR container's tritium fraction applicable to the GW2 time period. 


\subsection{RADIONUCLIDE DISPOSAL LIMITS}

The limits calculated in this SA supersede those calculated the previous SA for the initial TPBAR waste container. The change was required because of a significant reduction in the calculated tritium permeation rate of a single TPBAR waste container (see Reed, 2005). In this unclassified calculation the peak tritium emanation rate decreased from $6465 \mathrm{Ci} / \mathrm{yr}$ to $2210 \mathrm{Ci} / \mathrm{yr}$. The new limits for the air, radon, and groundwater pathways are shown in Table 4, and represent unique limits associated specifically with the initial phase (17) TPBAR waste containers.

Table 4. Radionuclide limits for the 17 production TPBAR waste containers

\begin{tabular}{|c|c|c|c||c|c|}
\hline Radionuclide & Air & GW1 & GW2 & Radon & Resident \\
\hline $\mathrm{H}-3$ & $9.4 \mathrm{E}+10^{\mathrm{a}}$ & $1.9 \mathrm{E}+09^{\mathrm{a}}$ & $2.0 \mathrm{E}+09^{\mathrm{a}}$ & $>1 . \mathrm{E}+20^{\mathrm{a}}$ & $>1 . \mathrm{E}+20^{\mathrm{b}}$ \\
\hline $\begin{array}{c}\text { All other } \\
\text { radionuclides }\end{array}$ & $>1 . \mathrm{E}+20^{\mathrm{a}}$ & $>1 . \mathrm{E}+20^{\mathrm{a}}$ & $>1 . \mathrm{E}+20^{\mathrm{a}}$ & & $\begin{array}{c}\text { Individual } \\
\text { limits }\end{array}$ \\
\hline
\end{tabular}

a TPBAR waste container specific limit.

b Limits established for the ILV in Flach and Hiergesell 2004.

A summary of the production TPBAR container inventory for the most significant radionuclides, along with the associated exposure pathway limits for the ILV and the fraction represented by the composite TPBAR inventory (17 containers) for each is presented in Table 5 . At the bottom of this table the Sum of Fractions is indicated for each pathway.

Table 5. Summary of Inventory, Pathway Limits, and Fraction

\begin{tabular}{|c|c|c|c|c|c|c|c|c|c|}
\hline & & \multicolumn{4}{|c|}{ Pathway Limits } & \multicolumn{4}{|c|}{ Fraction of Limit } \\
\hline & TPBAR & Resident & Air & GW1 & GW2 & Resident & Air & GW1 & GW2 \\
\hline \multirow[t]{2}{*}{ Nuclide } & Inventory & Limit $^{\mathrm{a}}$ & Limit $^{b}$ & Limit $^{b}$ & Limit $^{\mathbf{b}}$ & Fraction & Fraction & Fraction & Fraction \\
\hline & $(\mathrm{Ci})$ & (Ci) & (Ci) & (Ci) & (Ci) & & & & \\
\hline $\mathrm{H}-3^{\mathrm{c}}$ & $2.7 \mathrm{E}+06$ & & $9.4 \mathrm{E}+10$ & $1.9 \mathrm{E}+09$ & $2.0 \mathrm{E}+09$ & & 2.9E-05 & $1.4 \mathrm{E}-03$ & $1.4 \mathrm{E}-03$ \\
\hline Co-60 & $6.9 \mathrm{E}+05$ & $8.0 \mathrm{E}+08$ & & & & 8.6E-04 & & & \\
\hline \multirow[t]{2}{*}{ Nb-94 } & $9.7 \mathrm{E}+00$ & $1.3 \mathrm{E}+04$ & & & & 7.5E-04 & & & \\
\hline & & & & \multicolumn{2}{|c|}{ Sum of Fractions } & 1.6E-03 & 2.9E-05 & $1.4 \mathrm{E}-03$ & $1.4 \mathrm{E}-03$ \\
\hline
\end{tabular}

a for generic waste from Flach and Hiergesell 2004

b for only the 17 initial phase production TPBAR waste containers

c the composite tritium inventory for 17 initial phase production TPBAR containers 
WSRC-TR-2005-00531, Rev. 0

\subsection{CONCLUSIONS AND RECOMMENDATIONS}

The Department of Energy's Tritium Readiness Program has identified a plan to provide an ongoing source of tritium. This program involves the irradiation of specially manufactured rods called Tritium Producing Burnable Absorber Rods (TPBARs) within two Tennessee Valley Authority (TVA) reactors. The irradiated rods would then be transported to the Savannah River Site (SRS) in NAC transportation casks containers that provide the necessary shielding where they would be processed within the Tritium Extraction Facility (TEF) to remove the tritium. The plan then calls for four baskets of the extracted TPBARs to be loaded into the TEF shielded waste containers before its welded shut after which they will be placed in a Low-Level Waste (LLW) disposal facility at the SRS. Irradiation of the TPBARs at the TVA reactors has already begun and is expected to continue through approximately 2047. The first phase of TPBAR production is defined as those TPBARs produced in irradiation Cycles 6 through 25, for which an approximate irradiation schedule that extends through 2023 has been identified. This SA addresses only the proposed disposal of the anticipated 17 TEF waste containers that will contain TPBARS from Cycle 6-25 irradiation. Shipping of the first production cycle TPBARs to SRS has already begun and will continue through 2022 according to a staggered schedule as irradiation cycles are completed. Each waste container is expected to contain up to 1200 extracted TPBARs.

Two previous heat generation analyses suggest that the combined heat load of the initial 17 TPBAR containers when loaded into the ILV will not cause the critical heat load threshold temperatures to be exceeded (see Vinson, 2004 and Vinson, 2005). The relevant conditions include the ability of the CLSM material to cure properly at the time of emplacement $\left(\sim 200^{\circ} \mathrm{F}\right)$, the breakdown of structural integrity of cement-like material $\left(\sim 430^{\circ} \mathrm{F}\right)$, or the interference with other waste items disposed within the ILV. The staggered arrival schedule of waste containers, the rapid diminishing of the heat load of each container through time and the ability to maximize the distance between placement of individual containers within the ILV as they arrive are the most significant factors will allow the combined heat load to be minimized. It will be necessary, however, to ensure that each TPBAR waste container has been allowed to dissipate heat for at least 1.5 year after the completion of irradiation at the TVA reactor prior to its being encased within CLSM, so that its heat source term can diminish to that utilized in the Vinson, 2004 analysis (720 watts). Prudent management measures will be necessary to minimize the combined heat buildup in the ILV, including:

- Utilization of all available cells within the ILV (7) to maximize the lateral distance between TPBAR waste containers as they are placed within the ILV after arriving from the TEF.

- Placement of TPBAR containers in a horizontal position parallel to and close to the outer walls of cells. This configuration would maximize dissipation of heat, not only to the airspace immediately above the container prior to CLSM encasement, but also to the side wall after CLSM encasement.

- Use of a "double-stacking” arrangement of TPBAR waste containers along the outside edges of individual ILV cells. If there is metal-to-metal contact of waste containers, they will act as single unit, thermally, and will maximize the length of time that at least one side of the waste container unit is in contact with the overlying air space. Such contact will maximize the dissipation of heat.

- Periodic monitoring of CLSM temperature within the ILV, especially as adjacent cells have waste containers placed within them, would be useful to verify that the critical temperature ( $430{ }^{\circ} \mathrm{F}$ ) is not being approached.

- Ensuring that the trunions are placed at a slight distance from the ILV outer wall material such that there is assurance of full contact of the waste containers with CLSM. 
With respect to TPBAR container durability within the ILV disposal environment, another investigation (Vinson et al. 2004) indicated that the expected corrosion rate of the TPBAR waste containers' exterior carbon steel wall is slow enough that the wall will not be breached until a point in time that is well beyond the 1000-year PA compliance period. The durability of the TPBAR waste container will prevent the release of all non-tritium radionuclides within the 1000-year PA compliance period. Therefore, no further action is required to evaluate the air, radon, and groundwater pathways for those radionuclides (i.e., the limits for all radionuclides other than tritium for air, radon, and groundwater pathways are $>1 . E+20)$. However, due to its ability to permeate the exterior wall of the TPBAR container, tritium was evaluated with respect to the air and groundwater pathways. The tritium permeation rate was obtained from a previous investigation for use in these evaluations.

The air pathway analysis indicates the tritium that permeates the 17 TPBAR containers contributes a very small fraction, $2.89 \mathrm{E}-05$, to the annual exposure limit through the air pathway. With respect to the resident intruder pathway, the largest fraction contributed by any radionuclide in the entire inventory is 8.62E-04, for Co-60. The Sum of Fractions for the air and resident intruder pathways are calculated to be 2.89E-05 and 1.61E-03, respectively. These pathways are therefore of no further concern for the TPBAR waste container.

With regard to the groundwater pathway, the groundwater models developed in the recent SA to update ILV disposal limits were utilized to evaluate this pathway for the TPBAR container. Since the planned disposal represents the introduction of a significant tritium source term into compact zones, it was thought that such a disposal method could produce higher concentrations at the 100-meter compliance well than if considering a source term distributed uniformly throughout the ILV. Hence, the model was set up to depict the geometry of an actual TPBAR container and the tritium source term was introduced accordingly.

Since groundwater pathways are evaluated with respect to time, fractions are determined for the GW1 and GW2 time periods. The GW1 fraction applies to the $0-100$ year time period while the GW2 fraction applies to the $100-1350$ year time period.

The groundwater model results reflect groundwater tritium concentration at the 100-meter compliance well. For the 0-100 year period the maximum groundwater tritium concentration was determined to be $27.9 \mathrm{pCi} / \mathrm{L}$, which is the peak overall groundwater tritium concentration, and which was observed to occur at 99 years. The maximum concentration for the 100-1350 year period occurs at 101 years and was determined to be $27.8 \mathrm{pCi} / \mathrm{L}$. These tritium groundwater concentrations are very small relative to the MCL of 20,000 $\mathrm{pCi} / \mathrm{L}$ and result in the calculation of very small fractions for the GW1 and GW2 pathways, these being 1.4E-03 and 1.39E-03, respectively.

To implement the results of this SA in the Waste Information Tracking System (WITS), radionuclide disposal limits for the TPBAR waste container must be entered by using a unique designator for tritium limits associated with the GW1, GW2, Air and Radon pathways (e.g., H-3T). These limits are shown in Table 5. The limit for every other radionuclide for these pathways is $>1 \mathrm{E}+20 \mathrm{Ci}$. For the intruder pathway, the limits determined in the ILV SA (Flach and Hiergesell, 2004) should be used.

The conclusion of this SA is that the disposal of the initial 17 production TPBAR waste containers in the ILV will not cause any exceedance of DOE Order 435.1 performance measures over the 1000year PA compliance period and may therefore be disposed of within the ILV. Furthermore, with the use of prudent management measures, the combined heat load contributed to the ILV by these waste containers can be controlled such that no adverse impacts will be realized. Finally, considering the low impact of the 17 initial-phase waste containers with respect to the ILV disposal limits, it may be 
advantageous to consider disposal of all or some of these waste containers in an alternative disposal facility when the extended life-cycle TPBAR containers are analyzed to determine the most appropriate disposal pathway. 


\subsection{REFERENCES}

Brizes, W. F. 2004. Email correspondence of 2/27/2004 to E.L. Wilhite, et. al.

Flach, G.P., and R.A. Hiergesell, 2004. Special Analysis: Revision of Intermediate Level Vault Disposal Limits (U), WSRC-TR-2004-00346, Westinghouse Savannah River Company, Aiken, SC, 29808, 7/20/2004.

Hiergesell, R.A., and E.L. Wilhite, 2004. Special Analysis: Evaluation of the Proposed Disposal of the Initial GEF-TPBAR Waste Container Within the E-Area Low-Level Waste Facility Intermediate Level Vault, WSRC-TR-2004-00498, Rev. 0, Westinghouse Savannah River Company, Aiken, SC, 29808, November, 2004.

Kaplan, D.I., 2005. Estimate of Gaseous ${ }^{14}$ Carbon Concentrations Emanating from the IntermediateLevel Vault Disposal Facility (U), WSRC-TR-2005-00222, Rev. 0, Westinghouse Savannah River Company, Aiken, SC 29808.

M-CLC-A-00226, Transient Foundation Temperature below a Saltstone Vault with Sloped Walls, SRNL Calculation Cover Sheet, 5/16/2005.

Nowick, A.S. and J.J. Burton, ed. 1975. Diffusion in Solids - Recent Developments, Chapter 5, "Hydrogen Diffusion in Metals," Academic Press, New York, NY.

Pagh, R.T., 2004. Unclassified Bounding Source Term, Radionuclide Concentrations, Decay Heat, and Dose Rates for the Production TPBAR, TTQP-1-111, Rev. 4, Tritium Technology Program Procedure, Pacific Northwest National Laboratory, Richland, WA, 9/16/2004.

Reid, B.D. 2005. Email correspondence to W.F. Brizes of 9/21/2005.

Vinson, D.W., K.H. Subramanian and E.A. Clark, 2004. Containment Materials Performance for TPBAR Disposal, WSRC-TR-2004-00374, Westinghouse Savannah River Company, Aiken, SC, 29808, July, 2004.

Vinson, D.W., 2005. Thermal Analysis of the Tritium Extraction Facility Disposal Container in PreDisposal Configuration, WSRC-TR-2005-00087, Westinghouse Savannah River Company, Aiken, SC, 29808, February, 2005. 
WSRC-TR-2005-00531, Rev. 0

\section{APPENDIX}

\section{EMAIL TRANSMITTALS}

William Brizes/WSRC/Srs

02/27/2004 04:41 PM

\author{
To Elmer Wilhite/WSRC/Srs@Srs \\ Benjamin Snider/WSRC/Srs@Srs, Catherine \\ Flavin/BSRI/Srs@Srs, Dennis Grove/BSRI/Srs@Srs, Kevin \\ Tempel/WSRC/Srs@Srs, Rex Lutz/WSRC/Srs@Srs, Tom \\ ButcherMSRC/Srs@Srs, Welford03 \\ cc Goldston/WSRC/Srs@Srs, William Brizes/WSRC/Srs@Srs, \\ bobby-d.smith@srs.gov, Dale Parrott/BSRI/Srs@Srs, Les \\ Barrett/WSRC/Srs@Srs, Bob SnyderWSRC/Srs@Srs, Scott \\ Booth/WSRC/Srs@srs \\ bcc \\ Subject Re: TPBAR Radionuclide content
}

Elmer, the radionuclide content of a TPBAR is given PNNL document TTQP-1-111, Rev.2, 6/16/03, "Unclassified Bounding Source Term, Radionuclide Concentrations, Decay Heat and Dose Rates for the Production TPBAR". The document was sent to you in the mail.

After extraction the tritium content of a TPBAR is reduced from 1.2 grams to $133 \mathrm{Ci}$ per rod. That is $39,900 \mathrm{Ci}$ per 300 TPBARs, $119,700 \mathrm{Ci}$ 's for a group of 3 extraction baskets, and 159,600 Ci's for a group of 4 extraction baskets.

If one of the baskets contained the unextracted LTA TPBARs (32 TPBARs at 1.2 grams per rod decayed 8 years to 20.4 grams) the basket would contain 197,146 Ci's. The total curies in a waste container (three extraction baskets plus the LTA rods) would be 316,846 Ci's (119,700 Ci's + 197,146 Ci's ).

I hope this information is useful.

William F. Brizes

TEF/CLWR/Defense Programs

Westinghouse Savannah River Co.

Bldg. 233-34-H, Room 14

Aiken, SC 29808

803-208-8174 office

803-208-8198 fax

1-6446 pager

william.brizes@srs.gov

Elmer Wilhite/WSRC/Srs 
WSRC-TR-2005-00531, Rev. 0

William Brizes/WSRCISrs

09/22/2005 09:28 AM
To Robert HiergeselliSRNLSrs@Srs

cc Elmer Wilhite/SRNUS's@Srs, Tom Butcher'SRNUSrs@Srs, Elliot Clark'SRNLSSr@srs, Catherine FlaviniBSRIISrs@Srs, William Brizes/WSRCiSrs@Srs

— Forwarded by William BrizesiW/SRCiSrs on 09/22/2005 09:24 AM-

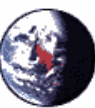

"Reid, Bruce D" <bruce.reid@pnl.gov>

09/21/2005 08:51 PM

$\begin{array}{rll}\text { To } & \text { "Brizes, william" <William.Brizes@srs.gov> } \\ \text { Sc } & \\ \text { Subject } & \text { FW: TABLE FOR TRANSMITTAL TO BRIZES }\end{array}$

Bill attached is the promised table

I can not elaborate in an unclassified venue. I hope this doesn't hurt too much, we tried hard.

-Bruce 
WSRC-TR-2005-00531, Rev. 0

This page intentionally left blank. 


\section{Distribution:}

J.E. Marra

J. C. Griffin

B. T. Butcher

J. R. Cook

G. P. Flach

R. Hiergesell

E. L. Wilhite

C.A. Flavin

W.F. Brizes

L. T. Reid

D. F. Sink

S. R. Reed

K. L. Tempel

S. E. Crook

D. G. Collins

W. T. Goldston

M.J. Ades

K. A. Stone

K.E. Harrawood

S. E. Booth

D. W. Bickley

D. E. Grove

B. D. Smith

E. A. Clark

WPT File

SW Document Control
773-A

773-A

773-43A

773-43A

773-42A

773-43A

773-43A

233-22H

233-22H

705-3C

704-56E

704-56E

704-56E

704-56E

706-N

705-3C

705-3C

704-60E

704-60E

233-22H

248-H

246-H

233-22H

773-A

773-43A

642-E 